\title{
IMPLEMENTASI LESSON STUDY MELALUI MODEL PEMBELAJARAN KOOPERATIF TEAM GAMES TOURNAMENT (TGT) PADA MAHASISWA PRODI PBSI STKIP MUHAMMADIYAH KOTABUMI
}

\author{
Windo Dicky Irawan*)
}

\begin{abstract}
This research is a qualitative descriptive research that aims to describe what it is about the activities of students study program in General Linguistics learning. Data collection is done by using planning stages (plan), implementation (do), and reflection (see) that focus on student activities. The subjects of this study are students of first semester of class A of PBSI study program. What is observed is the increase in student activity on each cycle. The research process is carried out with several stages: (a) conducting observations of research subjects, (b) performing data retrieval, (c) analyzing data on each cycle, (d) conducting discussion of the results of the analysis, (e) drawing conclusions of research results. The results showed that: 1) the implementation of learning through cooperative model Team Games Tournament can increase the activity, enthusiasm of students, 2) the implementation of learning with cooperative model Team Games Tournament can improve student ability.
\end{abstract}

Keywords: lesson study, cooperative learning TGT, student activity

\section{PENDAHULUAN}

Linguistik merupakan ilmu yang mengkaji bahasa sebagai objek kajiannya. Linguistik juga tidak hanya mengkaji sebuah bahasa saja, seperti bahasa Jawa atau bahasa Arab, tetapi juga mengkaji seluk-beluk bahasa pada umumnya, dan bahasa yang menjadi alat interaksi sosial milik manusia (Chaer, 2012:3).

Terkait dengan materi linguistik, dosen bertanggung jawab untuk mengajarkan mahasiswanya, sehingga mereka harus membutuhkan sejumlah pengetahuan, kecakapan dasar dan metode dalam melaksanakan tugasnya. Berkaitan dengan hal tersebut, maka dosen dituntut memiliki kemampuan dasar yang diperlukan sebagai pendidik sekaligus pengajar. Sebagai pengajar, dosen setidaknya harus menguasai bahan yang akan diajarkannya juga menguasai metode mengajar yang tepat.

Ada beberapa metode mengajar, baik yang bersifat "teacher centered" atau komunikasi dua arah, seperti model pembelajaran langsung, maupun yang bersifat "student-centered" atau komunikasi multi arah seperti model pembelajaran kooperatif. Namun, yang demikian terkadang yang menjadi kendala, yaitu jumlah mahasiswa yang begitu besar dalam satu kelas, fasilitas belajar yang kurang, kurangnya waktu dosen untuk membantu mahasiswa secara individu 
serta adanya keengganan sebagian mahasiswa untuk bertanya pada dosen.

Proses belajar mengajar selama ini masih menggunakan metode konvensional yang di dominasi oleh pengajar (dosen). Dalam hal ini pengajar (dosen) lebih menekankan kemampuannya pribadi dalam proses pembelajaran. Pengajar (dosen) tidak melibatkan metode komunikatif dan pendekatan secara persuasif dalam meningkatkan cara belajar khususnya materi linguistik umum. Salah satu alternatif pemecahan dari permasalahan di atas adalah dengan menggunakan model pembelajaraan kooperatif.

Model pembelajaran kooperatif merupakan rangkaian kegiatan belajar yang dilakukan oleh peserta didik dalam kelompok-kelompok tertentu untuk mencapai tujuan pembelajaran yang telah dirumuskan. Slavin (2009: 15) menyatakan bahwa model pembelajaran kooperatif adalah suatu model pembelajaran yang para peserta didiknya bekerja dalam kelompok-kelompok kecil untuk saling membantu satu sama lainnya dalam mempelajari materi pelajaran. Hal ini juga disampaikan oleh Isjoni (2009:15) bahwa pembelajaran kooperatif merupakan suatu cara pendekatan atau serangkaian strategi yang khusus dirancang untuk memberi dorongan kepada siswa agar bekerja sama selama proses pembelajaran.

Sejalan dengan pendapat Slavin dan Isjoni, Sugiyanto (2008:35) mengungkapkan bahwa pembelajaran kooperatif (cooperative learning) merupakan pendekatan pembelajaran yang berfokus pada penggunaan kelompok kecil peserta didik untuk bekerja sama dalam memaksimalkan kondisi belajar untuk mencapai tujuan belajar. Dalam model pembelajaran kooperatif ini terdapat lima unsur yang penting dalam pelaksananya, yaitu: saling ketergantungan positif, tanggung jawab perseorangan, tatap muka, komunikasi antaranggota, dan evaluasi proses kelompok (Johnson, dalam Lie, 2007:30).

Dari beberapa definisi di atas dapat diperoleh bahwa pembelajaran kooperatif merupakan salah satu pembelajaran efektif dengan cara membentuk kelompok-kelompok kecil untuk saling bekerja sama, berinteraksi, dan bertukar pikiran dalam proses belajar. Dalam pembelajaran kooperatif, belajar dikatakan belum selesai jika salah satu teman dalam kelompok belum menguasai bahan pelajaran. Selain itu juga, pengajar (dosen) kurang memanfaatkan mahasiswa untuk membantu temannya dalam belajar baik di dalam kelas maupun di luar kelas sebagai tutor. mahasiswa juga terlihat tidak memiliki keinginan untuk bertanya kepada pengajar (dosen), sehingga dalam proses pembelajaran kurang aktif.

Penyebab pengajar (dosen) kurang memanfaatkan mahasiswa sebagai tutor dalam pembelajaran karena pengajar (dosen) sudah terbiasa dengan metode pengajaran 
yang didominasi oleh dosen. Kemudian adanya kesulitan mengenai cara membuat skenario pembelajaran di kelas dengan memanfaatkan tutor dari salah satu anggota kelompok. Bagaimana cara memilih tutor dari salah satu anggota kelompok, proses pembelajaran dengan tutor dari salah satu anggota kelompok dan hal lain yang harus dilaksanakan oleh pengajar (dosen).

Salah satu alternatif pemecahan dari permasalahan di atas, yaitu dengan menggunakan model pembelajaraan kooperatif dengan memanfaatkan tutor dari anggota kelompok dan dilanjutkan dengan quis dalam bentuk games (TGT). Hal ini mengingat di dalam satu kelas mahasiswa mempunyai taraf kecerdasan yang heterogen karena terdapat mahasiswa yang pandai, sedang, dan kurang pandai. Mahasiswa yang pandai itulah yang difungsikan sebagai tutor. Metode belajar kelompok dengan tutor dapat diterapkan karena ada kalanya mahasiswa lebih mudah menerima penjelasan yang diberikan oleh teman-teman sebayanya. Bantuan tutor ini, diharapkan nantinya mahasiswa dapat menanyakan hal-hal yang kurang dipahaminya, sampai mahasiswa tersebut benar-benar mengerti.

Berdasarkan uraian di atas, penulis bermaksud mengimplementasikan lesson study melalui Model Pembelajaran Kooperatif Teams Games Tournament pada mahasiswa prodi PBSI semester 1 STKIP Muhammadiyah Kotabumi.

\section{Metode Penelitian}

Penelitian ini merupakan penelitian deskriptif kualitatif yang bertujuan untuk menggambarkan apa adanya tentang aktivitas mahasiswa dalam pembelajaran linguistik umum.Penelitian ini dilaksanakan di STKIP Muhammadiyah Kotabumi yang disetting sebagai kelas pembelajaran pada mata kuliah linguistik umum. Subjek pada kegiatan lesson study ini, yaitu mahasiswa prodi PBSI semester 1 kelas A tahun akademik 2017/2018.

Pengumpulan data dalam penelitian ini dilakukan melalui rekaman video pada setiap siklus dari praktik do yang dilakukan dosen model saat open class berlangsung dan berdasarkan pengamatan para observer. Sementara teknik validasi yang digunakan adalah perpanjangan pengamatan di setiap siklus.

Dalam penelitian kualitatif, analisis data dilakukan pada saat pengumpulan data sampai penarikan kesimpulan. Aktivitas dalam analisis data kualitatif dilakukan secara interaktif dan berlangsung secara terus menerus sampai tuntas, yang ditandai dengan data yang sudah jenuh.

\section{Hasil dan Pembahasan}

\section{Siklus Pertama Kegiatan Lesson Study}

Tindakan dalam siklus pertama diawali dengan menerapkan Model Pembelajaran Kooperatif. Pada pertemuan pertama ini dilakukan pembentukan kelompok menjadi 5 
kelompok dari 48 jumlah mahasiswa. yang diberikan, sedangkan beberapa Pemilihan anggota kelompok dibagi secara mahasiswa lainnya hanya memperhatikan heterogen, yaitu 10 orang tiap kelompok pendapat temannya tersebut. dengan menempatkan siswa yang Pada tahapan kegiatan inti berkemampuan tinggi di setiap kelompok pembelajaran, dosen model memberikan tersebut.

Adapun Komponen pendukung kesempatan untuk mendiskusikan tentang materi linguistik sebagai ilmu. Dalam diskusi terlaksananya pembelajaran pada siklus kelompok terlihat bahwa dari 10 orang tiap pertama yang dijadikan rancangan awal adalah sebagai berikut.

\section{a. Tahap Perencanaan (Plan)}

Tahapan perencanaan (plan) dimulai dengan menyampaikan pembelajaran yang akan dilaksanakan berdasarkan pada SAP yang telah dibuat. Topik materi yang akan dipaparkan pada siklus pertama adalah linguistik sebagai ilmu. Pada tahapan ini dosen model dan para observer mendiskusikan langkah-langkah yang digunakan agar mahasiswa dapat memahami materi serta media yang digunakan dalam proses pembelajaran.

\section{b. Tahap Pelaksanaan (Do)}

Kelas yang dijadikan sebagai kelas penelitian, yaitu kelas 1A yang berjumlah 50 mahasiswa. Kegiatan pembelajaran dimulai dengan dosen model membuka pembelajaran dengan memberikan pertanyaan-pertanyaan tentang materi yang akan dipelajari dengan mengaitkan pada kehidupan sehari-hari. Secara umum, hanya ada beberapa mahasiswa yang dapat menjawab pertanyaan-pertanyaan orang saja. Bahkan, ada beberapa kelompok yang melakukan diskusi hanya 3 orangn saja yang aktif dan antusias dalam diskusi sehingga dosen model mendatangi kelompok tersebut untuk memberi bimbingan khusus.

Langkah terakhir (kegiatan penutup), dosen model memberikan evaluasi pemahaman dengan memberikan kesempatan kepada beberapa mahasiswa untuk memberikan kesimpulan.

\section{c. Tahap Refleksi (See)}

Berdasarkan pengamatan yang dilakukan oleh para observer pada tahap pelaksanaan terlihat bahwa:

1. ada beberapa mahasiswa yang justru memperhatikan para observer,

2. masih banyak mahasiswa yang kebingunan dalam kerja kelompok,

3. tiap kelompok terlalu banyak jumlah anggotanya,

4. banyaknya jumlah anggota berdampak pada penyusunan tempat duduk yang tidak memungkinkan mahasiswa untuk dapat 
berdiskusi dengan semua anggota kelompok,

5. masih banyak mahasiswa yang kesulitan dalam proses pembelajaran,

6. kerja kelompok yang dilakukan mahasiswa tidak berjalan dengan baik, karena ada beberapa kelompok yang tidak dapat berdiskusi dengan semua anggota kelompoknya,

7. mahasiswa masih ragu untuk mengungkapkan pendapat dan menjawab pertanyaan-pertanyaan yang diberikan dosen model,

8. beberapa mahasiswa tidak dapat memahami subdisiplin ilmu linguistik,

Berdasarkan hasil diskusi dari tim lesson study, perlu dilakukan pembenahan dan perencanaan pembelajaran yang lebih matang untuk siklus kedua agar pelaksanaan lesson study ini berjalan dengan baik dan mampu mencapai tujuan yang direncanakan.

\section{Siklus Kedua Kegiatan Lesson Study}

Pelaksanaan kegiatan siklus kedua lebih difokuskan pada peningkatan aktivitas mahasiswa dalam bekerja kelompok. Siklus kedua mengangkat topik pembelajaran yang masih berkaitan dengan linguistik sebagai ilmu. Berdasarkan pengamatan yang dilakukan oleh observer pada tahap pelaksanaan terlihat bahwa:

1. dosen model pada siklus kedua ini menayangkan video di LCD yang berhubungan dengan materi sehingga membuat mahasiswa lebih antusias dalam memahami materi,

2. pembagian kelompok masih terlalu banyak jumlah anggotanya,

3. Pembagian kelompok masih berdampak pada penyusunan tempat duduk yang tidak memungkinkan mahasiswa untuk dapat berdiskusi dengan semua anggota kelompok,

4. kurangnya lembar kegiatan yang dibagikan sehingga beberapa mahasiswa dalam kelompok kurang aktif dalam kelompok,

5. masih ada beberapa kelompok yang tidak berdiskusi dengan anggota kelompoknya,

6. terlihat ada anggota kelompok yang hanya menyalin materi dari buku cetak yang dimilikinya.

Sementara hal-hal yang sudah mengalami peningkatan pada siklus kedua adalah sebagai berikut:

1. mahasiswa yang kesulitan dalam proses pembelajaran terlihat mengalami peningkatan,

2. diskusi kelompok yang dilakukan mahasiswa berjalan dengan baik meskipun terlihat ada beberapa kelompok yang kurang aktif dalam diskusi,

3. beberapa mahasiswa juga dari beberapa kelompok lebih aktif dan antusias pada saat games berjalan

4. mahasiswa lebih banyak yang ingin mengungkapkan pendapat dan menjawab 
pertanyaan-pertanyaan yang diberikan dosen model,

5. lebih banyak mahasiswa yang memperhatikan penjelasan-penjelasan dosen model dalam pembelajaran,

Berdasarkan hasil diskusi dari tim lesson study, perlu dilakukan pembenahan dan perencanaan pembelajaran yang lebih matang untuk siklus ketiga, agar pelaksanaan lesson study ini berjalan dengan baik dan mampu mencapai tujuan yang direncanakan.

\section{Siklus Ketiga Kegiatan Lesson Study}

Kegiatan siklus ketiga difokuskan pada keaktifan mahasiswa dalam diskusi kelompok untuk memahami materi. Tema materi yang diangkat adalah masih kelanjutan dari lingustik sebagai ilmu. Sementara kekurangan pada siklus kedua diusahakan mengalami perubahan menjadi lebih baik. Berdasarkan pengamatan yang dilakukan oleh dosen dan observer pada tahap pelaksanaan terlihat bahwa:

1. beberapa mahasiswa sudah dapat menjadi tutor pada anggota temannya yang belum paham dengan materi,

2. di kelompok yang lain masih juga ada beberapa mahasiswa tidak menyertakan diri dalam diskusi kelompok,

3. dengan dipecahnya lagi kelompok mejadi 10 kelompok, tiap kelompok masingmasing terdiri atas 5 anggota maka diskusi kelompok menjadi lebih efektif,
4. ketika games berjalan masih juga ada beberapa mahasiswa tidak turut aktif dalam permainan.

Berdasarkan hasil dari diskusi tim lesson study, dengan melihat pebaikanperbaikan pada siklus sebelumnya, mengalami peningkatan yang signifikan. Halhal yang sudah mengalami peningkatan pada siklus ketiga adalah sebagai berikut:

1. mahaiswa lebih antusias dalam mengikuti diskusi pembelajaran,

2. mahasiswa lebih aktif dalam kerja kelompoknya,

3. kerja sama mahasiswa dalam diskusi kelompok semakin meningkat,

4. dalam bermain games antusias dan semangat dari mahasiswa pun semakin meningkat, dapat dilihat dari banyaknya mahasiswa yang ingin menjawab pertanyaan dari kelompok lain,

5. tutor sebaya sangat membantu dalam diskusi pembelajaran

6. mahasiswa lebih antusias untuk mempresentasikan hasil kerja kelompoknya dan menyampaikan kesimpulan materi yang telah dipelajari.

\section{Simpulan dan Saran}

1. Simpulan

Melalui lesson study terlihat sangat jelas hubungan dan kerja sama yang baik antara dosen dengan dosen (observer), dosen dengan mahasiswa, dan mahasiswa dengan mahasiswa. Dosen terbantu karena adanya 
observer, dan mahasiswa dapat saling berbagi ilmu yang ditungkan dalam bentuk diskusi (koperatif). Melalui lesson study aktivitas dan antusias mahasiswa dalam pembelajaran semakin meningkat. Adapaun peningkatan dari mahasiswa melalui kegiatan lesson study ini adalah sebagai berikut:

a. kemampuan mahasiswa dalam berdiskusi, bertanya, dan menjawab pertanyaanpertanyaan dosen model semakin meningkat,

b. study centre terlaksana dengan baik, artinya mahasiswa telibat secara aktif dalam proses pembelajaran artinya pembelajaran berpusat pada siswa,

c. dan keaktifan dan antusias mahasiswa dalam mengikuti pembelajaran sampai habis semakin meningkat.

Melalui lesson study juga banyak perubahan-perubahan yang terjadi pada dosen, di antaranya:

a. dosen menunjukkan kerja sama yang baik dengan dosen yang lain (observer),

b. dosen tidak kaku dan semakin berani untuk tampil di depan observer,

c. kemampuan dosen melakukan inovasi pembelajaran mengalami peningkatan, d. dosen semakin berani dalam menggunakan media maupun metode pembelajaran,

2. Saran

Bagi peneliti yang berminat mengembangkan lebih lanjut penelitian ini, diharapkan mencermati kelemahankelemahan dan keterbatasan penelitian ini sehingga penelitian selanjutnya dapat menyempunakan hasil penelitian ini. Perlu juga diperhatikan karakteristik pada setiap mahasiswa yang yang akan diajar karena karakteristik setiap kelas berbeda-beda dan memerlukan perlakuan yang berbeda pula.

\section{Daftar Rujukan}

Chaer, abdul. 2012. Linguistik Umum. Jakarta: Rineka Cipta.

Isjoni. 2009. Pembelajaran Kooperatif. Surabaya: Surabaya University Press.

Lie, Anita. 2007. Mempraktikan Cooperative Learning di Ruang-Ruang Kelas. Jakarta: Grasindo.

Slavin, R, E. 2008. Cooperative Learning. Bandung: Nusa Media

Sugiyanto. 2010. Model-Model Pembelajaran Inovatif. Jakarta: Yuma Pustaka. 